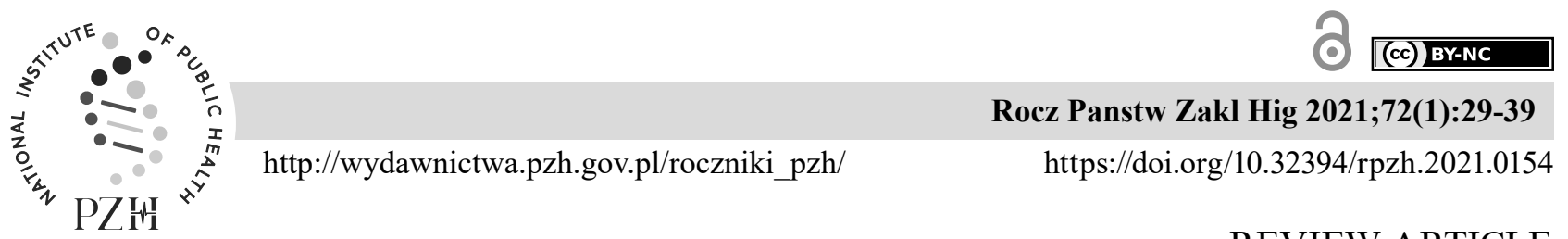

REVIEW ARTICLE

\title{
THE ROLE OF NUTRITION IN ALZHEIMER'S DISEASE
}

\author{
Sylwia Śliwińskal, Małgorzata Jeziorek ${ }^{2}$
}

${ }^{1}$ Wrocław Medical University, Faculty of Health Sciences, Department of Dietetics, Students Scientific Club, Wrocław, Poland

${ }^{2}$ Wrocław Medical University, Faculty of Health Sciences, Department of Dietetics, Wrocław, Poland

\begin{abstract}
The aging population is a significant social, medical and economic problem due to increasing prevalence of chronic diseases in elderly population. Alzheimer's disease (AD) is the most common form of dementia and the most common neurodegenerative disease. It is characterized by a progressive deterioration of memory and cognitive function. So far, there is neither an effective prevention nor cure for dementia, so more and more attention is paid to the prevention of this group of diseases, particularly to the appropriate diet. Preventive intervention gives the best results if introduced before the first symptoms of dementia, i.e., around the age of 50. This is when the nutritional status, number of synapses, cognition, and neuropathological changes in the nervous system compensate each other, which increases the chances of staying healthy for a longer period of time. It has been proven that dietary habits, which lead to the development of cardiovascular and metabolic diseases, significantly increase the risk of dementia. On the other hand, a Mediterranean diet rich in antioxidants, fiber and omega-3 polyunsaturated fatty acids may have a protective effect on the neurodegenerative process. The beneficial effect of many nutrients on the course of AD has been demonstrated. These include: glutathione, polyphenols, curcumin, coenzyme Q10, vitamins B6, B12, folic acid, unsaturated fatty acids, lecithin, UA, caffeine and some probiotic bacteria. A diet rich in saturated fatty acids and branched-chain amino acids (BCAA) promotes the progression of dementia. Dietary intervention should be introduced as early as possible to minimize the risk of developing dementia. The Mediterranean and DASH diets have been documented to protect against AD. However, the MIND diet is reported to be much more effective in preventing cognitive decline/dementia than either the Mediterranean or DASH diets alone.
\end{abstract}

Key words: Alzheimer's disease, nutrients, Mediterranean diet, MIND diet

\section{STRESZCZENIE}

Starzenie się społeczeństwa stanowi istotny problem społeczny, medyczny oraz ekonomiczny ze względu na częstsze występowanie chorób przewlekłych w tej grupie wiekowej. Choroba Alzheimera jest najczęściej występującą postacią demencji i jednocześnie najpowszechniejszą chorobą neurodegeneracyjną. Charakteryzuje się pogorszeniem pamięci i funkcji poznawczych oraz ma charakter postępujący. Do tej pory nie wynaleziono skutecznego sposobu leczenia chorób otępiennych w związku z tym coraz częściej zwraca się uwagę na prewencję tej grupy chorób, szczególnie odpowiedniego sposobu żywienia. Najlepsze efekty interwencji profilaktycznej występują wtedy, gdy jest ona wprowadzona jeszcze przed pojawieniem się pierwszych objawów otępienia, czyli około $50 \mathrm{r}$. ż. Wtedy stan odżywienia, liczba synaps, funkcje poznawcze oraz zmiany neuropatologiczne w układzie nerwowym wzajemnie się kompensują, co zwiększa szanse na zachowanie zdrowia przez dłuższy czas. Wykazano, że nawyki żywieniowe prowadzące do rozwoju chorób układu krążenia oraz zaburzeń metabolicznych, znacząco zwiększają ryzyko wystąpienia demencji. Ochronny wpływ na proces neurodegeneracyjny może mieć żywienie o charakterze diety śródziemnomorskiej, bogatej w antyoksydanty, błonnik oraz wielonienasycone kwasy tłuszczowe omega 3. Udowodniono również korzystny wpływ wielu składników diety na przebieg choroby Alzheimera. Należą do nich: glutation, polifenole, kurkumina, koenzym Q10, witaminy B6, B12 i kwas foliowy, nienasycone kwasy tłuszczowe, lecytyna, kwas moczowy, kofeina oraz niektóre bakterie probiotyczne. Dieta bogata w nasycone kwasy tłuszczowe oraz aminokwasy o rozgałęzionym łańcuchu wykazuje działanie promujące postęp otępienia. Interwencja dietetyczna powinna być wprowadzona możliwie jak najwcześniej, by zminimalizować ryzyko rozwoju chorób otępiennych. Diety o najlepiej udokumentowanych korzyściach w przebiegu choroby Alzheimera to dieta śródziemnomorska i DASH. Natomiast dieta MIND okazała się znacznie skuteczniejsza w prewencji otępienia niż dieta śródziemnomorska i dieta DASH.

Słowa kluczowe: choroba Alzheimera, składniki diety, dieta śródziemnomorska, dieta MIND

Corresponding author: Małgorzata Jeziorek, Wroclaw Medical University, Faculty of Health Sciences, Department of Dietetics, 34 Parkowa str., 51-616 Wrocław, Poland, tel. +48 515-746-698, e-mail: malgorzata.jeziorek@umed.wroc.pl

(C) Copyright by the National Institute of Public Health - National Institute of Hygiene 


\section{INTRODUCTION}

Alzheimer's disease (AD) is the most common form of dementia and, at the same time, the most common neurodegenerative disease characterized by the progressive deterioration of memory and cognitive functions. Acetylcholine (Ach) deficiency, abnormal brain amyloid deposits and disorders of cholinergic transmission play an important role in the pathomechanisms of $\mathrm{AD}[5,35,41]$. Currently, there are no effective therapies to treat dementia syndromes. Currently, patients with AD receive only symptomatic treatment, which has been proven to slow down the disease progression [64]. Nevertheless, preventative measures help reduce the risk of disease. Proper diet, in addition to being physically and mentally active, can also be effective [12,34]. Dietary habits that lead to the development of cardiovascular and metabolic diseases have been reported to significantly increase the risk of dementia [9, 12]. A Mediterranean diet rich in antioxidants, fiber and omega-3 polyunsaturated fatty acids may also have a protective effect on degenerative process in $\mathrm{AD}[15,53]$.

Preventive intervention gives the best results if introduced before the first symptoms of dementia appear, i.e., around the age of 50. This is when the nutritional status, number of synapses, cognition, and neuropathological changes in the nervous system compensate each other, which increases the chances of staying healthy for a longer period of time [36].

Our study aimed to describe the role and effectiveness of a diet in the course and treatment of AD.

\section{ANTIOXIDANTS}

Brain tissue is very susceptible to damage, including the one caused by free radicals. Oxidative stress is a condition in which the amount of endogenous or exogenous reactive oxygen species (ROS) exceeds the antioxidant capacity of the cell or organism. There are also non-enzymatic antioxidants such as vitamin $\mathrm{E}$, vitamin $\mathrm{C}$, provitamin and vitamin $\mathrm{D} 3$, vitamin A, UA, carotenoids, glutathione, cysteine, creatinine, tocopherols, coenzyme Q10, bilirubin, polyphenols and anthocyanins. In addition, some essential elements, such as selenium, zinc and copper, serve as cofactors for protein cofactors or enzymes with antioxidant activity. It has been shown that oxidative stress may mediate the pathogenesis and progression of dementia, so dietary antioxidants are protective against the risk of cognitive decline [38]. However, these results are not conclusive. Some studies demonstrated that middle-aged taking with their diet vitamins $\mathrm{E}$ and $\mathrm{C}$, carotenoids and flavonoids had lower risk of developing AD in the future. However, most of the studies do not confirm the effectiveness of vitamin $\mathrm{C}$ and $\beta$-Carotene in improving cognitive functions [15]. Regardless of the study results, patients are encouraged to follow antioxidant-rich diet. Vegetables and fruits are rich in antioxidants and their regular consumption may positively affect health and slow down AD development [50]. Moreover, elderly people have significant vitamin deficiencies due to impaired digestion, nutrients absorption or metabolic disorders. They need less energy so they consume less food, which, in result, leads to insufficient supply of vitamins and minerals [7].

The main antioxidant in human plasma, vitamin C, acts as a scavenger of ROS, such as superoxide radical ion, hydroxyl radical or singlet oxygen. Moreover, it has a protective effect against tocopherols by regenerating them from the radical form. However, most of the studies have not demonstrated the positive effect of ascorbic acid on the improvement of cognitive functions. Similar conclusions apply to vitamin A [50].

Vitamin E (tocopherol) is recognized as the one of the most potent lipophilic antioxidants. It prevents the oxidation of unsaturated fatty acids, which are important building blocks for cell membranes, by interrupting the production of free superoxide radicals. Research regarding the effectiveness of vitamin E give contradictory results. Some studies have demonstrated that the incidence of dementia and AD decreased with the increasing supply of vitamin $\mathrm{E}$ in diets of people aged 55 or 65 , whereas other studies have failed to show such effects [50]. However, researchers indicate that elderly people are frequently deficient in tocopherol, so it is recommended to ensure its adequate dietary intake. The main sources of vitamin $\mathrm{E}$ are products of plant origin, i.e., vegetable oils, nuts, seeds, green leafy vegetables and some fatty fish (sardines, salmon, herring, trout) or chicken egg yolk [7].

The effectiveness of antioxidant vitamins in $\mathrm{AD}$ treatment should be considered taking into account the status of an active smoker. The protective effect of antioxidants was more pronounced among tobacco smokers. This correlation suggests that increased intake of dietary antioxidants may have clinical application under conditions of high oxidative stress [69].

Glutathione is a tripeptide comprised of three amino acids (glutamate, cysteine and glycine), which plays an important role in the antioxidant system. Glutathione is commonly found in food, although in small amounts, so its daily intake does not significantly increase plasma glutathione levels. Nevertheless, consuming glutathione-rich foods help decrease oxidative stress. A decreased concentration of glutathione is observed in the course of neurodegenerative diseases, and it is indicated that its increased cellular concentration may contribute to slowing or mitigating disease progression [27]. The best dietary sources of glutathione include fresh fruits and vegetables such 
as spinach, broccoli, asparagus, cabbage, garlic, onions, avocado, watermelon and strawberries, as well as walnuts, milk thistle, turmeric and freshly cooked meat. Food processing significantly decreases the amount of glutathione found in food, so canned products are not a good source of this antioxidant. We should also pay attention to the appropriate supply of glutathione precursors, e.g., cysteine and methionine, which can be found in beef, poultry, eggs, as well as in goat's, sheep's and cow's milk. The neuroprotective activity of glutathione involves removing reactive oxygen species and regenerating antioxidant vitamins $\mathrm{C}$ and $\mathrm{E}[68]$.

Ubiquinol, the reduced form of coenzyme Q10 (CoQ10), has similar antioxidant properties as glutathione. By removing ROS, it prevents damage to proteins and DNA and suppresses lipid peroxidation. It stabilizes cell membranes and regenerates vitamin E. Moreover, CoQ10 has been proven to protect against amyloid- $\beta$-induced neurotoxicity and improve synaptic plasticity [29]. Physiologically, the body produces an optimal amount of coenzyme Q10, but its cell concentration decreases due to the aging process and in the course of some diseases. In such cases, it is crucial to include food sources of Q10, i.e., rapeseed oil, beef, pork liver, tuna, herring, trout and chicken. In smaller amounts, CoQ10 can be found in blackcurrant, cauliflower, peas, and yoghurt. CoQ10 supplement should be consider if dietary intake is insufficient. Many studies have shown that B vitamins (i.e., B2, B6, B12, folic acid and pantothenic acid) enhance the biosynthesis of coenzyme Q10 [15, 51].

Polyphenols are a large heterogeneous group of compounds with antioxidant properties, naturally found in plants. There is known a few thousands various polyphenols considering different subtypes such as flavonols, flavanols, flavones, flavonones, and catechines as well as phenolic acids, lignans, and stilbenes [28]. The most significant polyphenols in AD are described in the following review. The antioxidant properties of polyphenols include capturing, scavenging and limiting ROS production. Moreover, flavonoids protect vitamins $\mathrm{C}$ and $\mathrm{E}$ and glutathione against oxidation and are able to chelate transition metals, such as iron and copper. These metal ions catalyze the autoxidation of neurotransmitters such as dopamine, serotonin and norepinephrine, and promote peroxidation of lipids contained in the cell membrane, leading to its destabilization. Curcumin and resveratrol are naturally occurring polyphenols. Results from in vitro studies showed that curcumin, isolated from the rhizome of turmeric, prevents amyloid- $\beta$ aggregation. Similar observations were reported in in vivo studies, which additionally proved that curcumin not only prevents aggregation of new amyloid deposits but even reduces the size of remaining ones $[18,69]$. Moreover, curcumin has been proved to increase the concentration of glutathione and antioxidant enzymes (superoxide dismutase and catalase) in the brains of rats exposed to lead and significantly reduced the damage from lead poisoning. Moreover, curcumin reduced levels of oxidized proteins and interleukin 1B in the brains of experimental mice. In vivo studies have shown that curcumin protects neurons from toxic effects of amyloid- $\beta$ protein and human endothelial cells from amyloid- $\beta$-induced oxidative stress. Additionally, it binds to transition metals (iron and copper) and neutralizes the damage caused by inflammation. Human studies have shown that curcumin increases uptake of amyloid- $\beta$ by macrophages of AD patients and inhibits peroxidase in $\mathrm{AD}$ patients $[45,58]$.

Resveratrol, which also belongs to the family of polyphenolic compounds, has significant antioxidant properties. In addition to its anti-inflammatory and antiviral effects, resveratrol has been shown to protect against neurological diseases by activating antioxidant enzymes in cells (such as glutathione) and protect microglia cells. The neuroprotective effects of resveratrol include the inhibition of toxic amyloid- $\beta$ aggregation in hippocampus by improving the activity of kinase $\mathrm{C}$ and proteasome complex and facilitating the breakdown of amyloid precursor protein. Resveratrol is claimed to be a promising agent in $\mathrm{AD}$. However, some studies demonstrated negative effects of resveratrol. High-dose resveratrol supplementation ( $3 \mathrm{~g} / \mathrm{kg}$ b.w./day) led to reduced appetite and weight loss. Moreover, resveratrol and its metabolites can penetrate the blood-brain barrier and lead to diarrhea, vomiting, leukocytosis, and decrease in hemoglobin, hematocrit and erythrocytes. Further negative symptoms of high-dose resveratrol supplementation include hyperplastic changes of kidneys and gallbladder. On the other hand, low-dose resveratrol supplementation ( $0.3 \mathrm{~g} / \mathrm{kg}$ b.w./day for 4 weeks) did not cause any side effects $[19,30]$. Despite inconclusive results, authors of these studies suggested positive correlation between increased consumption of products rich in polyphenols and lowered risk of cognitive decline and neurodegenerative diseases [49]. Studies in animals have shown that flavonoids found in berries, tea and cocoa can improve cognitive performance. Similar results were obtained in human studies, which showed an inverse relationship between dietary flavonoids and the incidence of $\mathrm{AD}$ and dementia, and a lower risk of dementia in older age [15]. Polyphenols are rapidly absorbed and metabolized, so they should be consumed with the diet. Polyphenols can be found in many foods such as berries, apricots, apples, kiwi, citrus fruits, red onions, tomatoes, peppers, lettuce, broccoli, cabbage, celery, parsley, cereals, soybeans, cocoa, as well as in drinks: tea, grapefruit juice, blueberry juice, grape juice, cherry juice, and red wine. Another disadvantage 
of polyphenols is their low bioavailability. Heattreatment of vegetables and fruits reduces the amount of flavonoids. It has been reported that combining the piperine in black pepper with curcumin enhances curcumin bioavailability. Moreover, divalent elements, fiber-rich meals and protein may lower the bioavailability of polyphenols [21, 62].

\section{VITAMINS B6, B12 AND FOLIC ACID}

Vitamin B12 deficiency is associated with cognitive impairment [40]. Moreover, vitamins B6, B12 and folic acid play a key role in metabolism of homocysteine, a by-product with different mechanisms of toxicity. It has been shown that a $5 \mu \mathrm{mol} / \mathrm{L}$ increase in serum homocysteine concentration may lead to ischemic stroke and atherosclerosis of large blood vessels. In addition to its atherogenic effect and inducing atherosclerosis, homocysteine is also considered a neurotoxin. Moreover, its elevated serum concentration is observed in patients with AD. It has been shown that elevated homocysteine levels can destroy dopaminergic neurons in vitro, induce motor impairment in rats, inhibit hippocampal neurogenesis in adult animals, disrupt the blood-brain barrier, and generate ROS. Moreover, elevated homocysteine levels can induce and enhance inflammation, increase the concentration of amyloid- $\beta$ precursor protein, promote tau protein phosphorylation, and exacerbate amyloid- $\beta$ pathology. Therefore, elevated homocysteine promotes cognitive dysfunction [10].

Homocysteine, the demethylated derivative of methionine, can be metabolized into cysteine or methionine, and these two different metabolic pathways require vitamins B2, B12, B6, and folic acid cofactors. Hyperhomocysteinemia arises from disrupted transmethylation of homocysteine to methionine, which may result from vitamin B12 and B6 deficiency or excessive intake of methionine. Homocysteine induces neurotoxicity, so in the prevention and treatment of $\mathrm{AD}$ it is important to monitor the concentration, intake and supplementation of vitamins B12 and B6. There is a relationship between oxidative stress and neurological disorders [53, 65].

The main sources of vitamin B6 are whole grains, pulses, nuts and seeds. Vitamin B12 is naturally found in dairy and meat, as well as in fortified foods. Rich source of dietary folate are leafy green vegetables, oranges, grapefruits and legume seeds. To prevent hyperhomocysteinemia, it is recommended to increase vitamin B6 intake to $2 \mathrm{mg}$, vitamin B12 to $3 \mu \mathrm{g}$, and folic acid to $400 \mu \mathrm{g}$. Higher doses are recommended for homocysteinemia treatment: $6-25 \mathrm{mg}$ of vitamin B6, 100-600 $\mu \mathrm{g}$ of vitamin B12, and $500 \mu \mathrm{g}$ of folic acid. Supplementation should be considered if such amounts of vitamins cannot be supplied with the diet
[50, 53]. Hyperhomocysteinemia is caused not only by vitamin $\mathrm{B}$ deficiency, but also by environmental factors such as excessive alcohol consumption and smoking. Elevated serum homocysteine levels are also associated with the use of certain drugs, such as levodopa [15]. Although the relationship between hyperhomocysteinemia and AD has not been fully investigated, it is believed that increased dietary intake of vitamins B6, B12 and folic acid may have a protective effect on the nervous system, thus reducing the risk of developing $\mathrm{AD}[50,65]$.

\section{FATTY ACIDS}

Improper dietary intake of saturated fatty acids (SFAs) and unsaturated fatty acids may be a risk factor for many diseases, including neurological disorders [22]. High intake of SFAs and trans isomers is a serious risk factor for civilization diseases, including cardiovascular disorders. Excessive intake of SFA can exacerbate cognitive impairment. On the other hand, individuals consuming large amounts of foods rich in monounsaturated (MUFAs) and polyunsaturated fatty acids (PUFAs), especially from the omega-3 family, had a significantly lower risk of dementia $[16,53]$.

Fatty acids are the main structural components of cell membranes. The properties of fatty acids depend on their chain length and the number of double bonds. Polyunsaturated fatty acids are major building blocks of neurons of particular importance for the brain. Due to double bonds, MUFAs and PUFAs, unlike SFAs, act as antioxidants. There is a negative correlation between increased consumption of PUFAs and increased homocysteine levels. Moreover, MUFAs promote glucose metabolism by improving pancreatic $\beta$-cell function, thereby improving postprandial glycaemia and insulin sensitivity. It has been shown that diet rich in MUFAs prevents deterioration of cognitive functioning [48]. Monounsaturated fatty acids can be found in olive oil, rapeseed oil, avocados, hazelnuts, peanuts, almonds and pistachios [16, 53].

Polyunsaturated essential fatty acids (PUFAs), including linoleic acid (LA) of the omega- 6 family and alpha-linolenic acid (ALA) of the omega-3 family play the most important role in the human body. Humans cannot synthesize PUFAs, thus PUFAs must be obtained from the diet. Linoleic acid is found in vegetable oils such as soybean, sunflower, corn, safflower and evening primrose oils. Foods high in alpha-linolenic acid include walnuts, as well as linseed, rapeseed, and soybean oils. Linoleic acid is a precursor in the synthesis of arachidonic acid (AA) and $\alpha$-linolenic acid is a substrate for the synthesis of longer chain omega fatty acids like eicosapentaenoic (EPA) and docosahexaenoic (DHA) acids [15, 37]. 
It has been shown that DHA accelerates the formation of new synapses and promotes neuronal development by extending axonal and dendritic branching. Moreover, DHA has cytoprotective, neuroprotective and anti-inflammatory properties. Ageing is accompanied by a decreased activity of enzymes, including $\Delta$-4-desaturase, which leads to impaired DHA synthesis, thus to disturbances in the functioning of the nervous system, and in consequence to AD [37]. Due to their antioxidant properties, DHA derivatives eliminate toxic effects of free oxygen radicals and protect against neuronal damage and apoptosis. Moreover, DHA helps maintain optimal concentration of brain phosphatidylserine, which can inhibit neuronal cell death $[52,63]$. Polyunsaturated fatty acids can improve cognitive functions and support learning and memory processes. It has also been shown that high dietary DHA intake inhibits neurodegenerative processes and formation of amyloid- $\beta$ deposits. Moreover, it protects against brain atrophy during AD progression $[22,31]$. Foods rich in EPA and DHA include oily sea fish such as herring, mackerel, sardines, salmon and tuna, as well as some shellfish. Recommended intake of EPA and DHA is $250 \mathrm{mg}$ per day for Polish adults which is equivalent to consuming 2 servings of oily fish per week [24]. European Food Safety Authority (EFSA) dietary recommendations for EPA and DHA based on cardiovascular risk considerations for European adults are between 250 to $500 \mathrm{mg} /$ day. It is also important to maintain an optimal balance between n-3 and n-6 PUFAs. Even a short-term imbalance may disrupt the nervous tissue. Arachidonic acid (AA) displaces DHA from membrane phospholipids, which enhances cell aggregation and leads to the synthesis of proinflammatory cytokines and neurotoxic metabolites [56]. Dietary sources of AA include meat, lard, fish, and egg yolks. The optimal n-6: n-3 (linoleic acid: alpha-linolenic acid) recommended by the Polish Cardiac Society is 4-5:1 or less. An adequate intake of omega-3 PUFAs, especially DHA, is crucial for nervous system development and functioning, both in adolescents and in the elderly $[15,53]$.

Conjugated linoleicacid(CLA) is the one of naturally occurring trans fatty acid. CLA, both with vaccenic acid, are found in ruminant derived products such milk and meat [20]. CLA's double bonds are conjugated, which means that they are separated by a single bond. A reduced phospholipase A2 (PLA2) activity in the cell membrane has been reported in patients with AD. Phospholipase A is known to play an important role in the pathogenesis of neurological diseases, including AD. It has been demonstrated that CLA modulates the activity of PLA2, thus improving cognitive function and memory [17]. Another enzymatic disorder that can lead to the development of neurodegenerative diseases is deregulation of cyclin-dependent kinases (CDKs), enzymes controlling all aspects of cell division. Recent studies in mice indicate that the supplementation with CLA may restore the proper regulation of CKDs and protect against oxidative mitochondrial damage. Moreover, it has been reported that decreased accumulation of amyloid- $\beta$ and its precursor protein in the brains of mice prevented cognitive decline. Researchers indicate that the supplementation with CLA may prevent or delay the onset of neurodegenerative diseases such as AD or Creutzfeldt-Jakob disease [6]. In addition to its neuroprotective effect, CLA is also used to treat obesity and cardiovascular diseases. Moreover, CLA stimulates thermogenesis and inhibits the activity of the lipoprotein lipase (LPL) by reducing the accumulation of adipose tissue. Conjugated linoleic acid occurs naturally in ruminant milk and dairy products, lamb, beef, and pork. However, the majority of studies on CLA have been performed in vitro or in experimental animals. Moreover, dietary interventions carried out in animals and humans were performed with the use of synthetic CLA, which has a different isomer balance to the naturally occurring CLA found in dairy [6].

Phospholipid fatty acids are fundamental building blocks of cell membranes. Phosphatidylcholine, a major component of lecithin, is one of the main phospholipids that make up nerve cell membranes, myelin sheaths, receptors and enzymes [56]. Lecithin has been shown to improve cognitive abilities, memory and concentration [8, 32]. It can be found in egg yolks, liver, soybeans, sunflower seeds, wheat germ and peanuts. Docosahexaenoic acid, uridine and choline (a substrate for acetylcholine synthesis) are phosphatidylcholine precursors. As a result of neuronal atrophy, patients with AD have lower levels of phosphatidylcholine, serotonin and noradrenaline. Choline-containing phospholipids such as lecithin and sphingomyelin are necessary for their synthesis. Choline is found predominantly in animal-derived foods such as beef, pork, poultry, eggs and fish, which are also sources of betaine. Plant products, such as nuts and broccoli, have lower levels of choline and contain only small amounts of betaine [66]. The adequate intake (AI) of choline recommended by the (EFSA) has been set at $400 \mathrm{mg}$ per day for adults. However, in a study conducted by Moreno Moreno [13], a therapeutic effect in AD patients was achieved after supplementation with $400 \mathrm{mg}$ of choline alfoscerate (Alpha-GPC) three times daily, for 180 days.

\section{URIC ACID}

In many epidemiological studies, hyperuricemia has been recognized as an independent risk factor for cardiovascular diseases. However, uric acid (UA) may 
also be beneficial due to its antioxidant properties, which may be particularly important in the context of neurodegenerative diseases [10, 54]. Besides its strong antioxidant properties, UA also acts as an iron chelator [1]. The use of UA should be analyzed with regard to the etiology of cognitive impairments.

It has been shown that in the case of $\mathrm{AD}$ and subcortical dementia syndrome of Parkinson's disease, elevated serum UA levels inhibited the disease progression $[10,57]$. Similar results were obtained in patients with mild cognitive impairment, but it should be emphasized that UA was a protective factor only if its levels were high long before $\mathrm{AD}$ onset. The protective effect against degenerative diseases was moderate but significant [70].

It has been shown that elevated levels of serum UA are associated with the progression of cognitive impairment in vascular or mixed dementia. Moreover, elevated UA can increase the risk of stroke and affect vascular cognitive impairment [57].

Diet affects serum UA concentration. Uric acid is the end product of purine metabolism. Purines are obtained from the breakdown of body proteins. They are found in meat, offal, fish, seafood, mushrooms and vegetables such as broccoli, Brussels sprouts, leek, green peas, cauliflower, corn, spinach, paprika, as well as in alcoholic beverages such as beer, vodka and wine. Products rich in fructose (honey and sweets) are also linked with elevated serum UA levels. Cruciferous vegetables, such as kale, savoy cabbage, red cabbage, napa cabbage, as well as legume seeds, pumpkin, green beans and some fruits such as melon and banana, are moderately high in purines. High consumption of dairy products and grains lowers blood UA levels. Some vegetables (beets, zucchini, white cabbage, lettuce, carrots, onions, tomatoes, cucumbers, potatoes, radishes) and fruits (pineapple, gooseberries, peaches, kiwi, pears, oranges, grapes, sweet and sour cherries, and berries), as well as nuts and seeds have a similar effect. Hypouricemia is associated with a faster progression of cognitive disorders and is regarded as a marker of malnutrition [57].

\section{CAFFEINE}

Caffeine occurs naturally in coffee beans, cocoa and guarana, yerba-mate, tea leaves and Cola acuminata, as well as in 60 other plant species. Caffeine or its metabolites (guaranine, theine, methyltheobromine or methyltheophylline) are added to energy drinks. Caffeine is quickly absorbed by the gastrointestinal tract and it rapidly penetrates cell membranes and the blood-brain barrier (BBB). Its bioavailability is nearly $100 \%$. Caffeine is pharmacologically active within a few minutes after consumption and reaches peak plasma concentration after 40 minutes [15].
Caffeine, a psychoactive and neurostimulating substance and one of the main ingredients in coffee, can enhance cognitive activity in the elderly people. Caffeine stimulates the central nervous system and antagonizes adenosine $\mathrm{A} 1$ and $\mathrm{A} 2$ receptors, which affects the release of neurotransmitters (acetylcholine, dopamine and noradrenaline), increases the activity of dopamine, strengthens its affinity for the D2 receptor, and protects dopaminergic receptors against toxic factors. Nevertheless, many other mechanisms might also explain beneficial effects of caffeine. Studies carried out on animal models demonstrated that caffeine has strong anti-inflammatory and antioxidant properties, increases mitochondrial function and supports glucose metabolism. Consuming products rich in caffeine improves concentration, alertness, mood, cognitive and psychomotor functions, as well as physical performance. Moreover, coffee polyphenols have protective effects in the treatment of $\mathrm{AD}[15,67]$.

In addition to its short-term effects, caffeine can also prevent cognitive impairment and dementia thanks to its neuroprotective and neuromodulatory properties. Experimental studies on animals demonstrated that caffeine decreases brain amyloid- $\beta$ levels by inhibiting enzymes involved in amyloid- $\beta$ synthesis. Moderate coffee intake, i.e., 5 cups per day (about $500 \mathrm{mg}$ of caffeine), showed therapeutic effects in humans [3]. However, a study assessing cardiovascular risk factors, aging and dementia showed that daily intake of 3-5 cups of coffee in middle-age lowered the risk of dementia or AD by $64 \%$ in older age [10]. Moreover, it has been demonstrated that caffeine prevents memory impairment caused by hyperhomocysteinemia [2]. On the other hand, some studies reported no relationship between caffeine intake and improved cognitive functions or even its negative impact on cognitive performance [53,67].

\section{PROBIOTICS}

Metabolites secreted by gut bacteria may affect cognitive performance of people with neurological diseases. It has been shown that changes in the composition of gut microbiota may influence depressive disorders as both an etiological and therapeutic factor. Beneficial properties of probiotic bacteria result from anti-inflammatory effect on the digestive system. Probiotics maintain intestinal barrier integrity, thereby preventing its permeability and leakage of pro-inflammatory substances from the intestinal lumen into the bloodstream (e.g., metabolites of pathogenic bacteria, food allergens). Released pro-inflammatory cytokines, interleukins and chemokines intensify the inflammation, which is associated with neurological diseases, including cognitive and depressive disorders [25, 42]. 
It has been demonstrated that gut microbiota influences human brain function via the microbiomegut-brain axis. Gram-positive Lactobacillus brevis and Bifidobacterium dentium produce gamma aminobutyric acid (GABA), which is the main inhibitory neurotransmitter in the central nervous system responsible for decreasing corticospinal excitability during muscle relaxation. Postmortem examination of patients with AD showed a decreased GABA concentration in the frontal, temporal and parietal cortex as compared to patients without cognitive impairment. It has been shown that there is a correlation between GABA levels in the central nervous system and GABA receptors in the gastrointestinal tract [55].

Animal studies have shown that gut microbiota can alter the levels of neurotransmitter-related metabolites. Moreover, it has the ability to release other bioactive signaling molecules such as short chain fatty acids, catecholamines and serotonin. In turn, increased serotonin signaling is associated with reduced amyloid plaque formation, and thus with the lower risk of developing AD [55]. It has been shown that probiotics, particularly Lactobacillus spp., can improve synaptic plasticity, stimulate hippocampal neurogenesis by increasing the concentration of brain-derived neurotrophic factor (BDNF) and regulate the hypothalamus-pituitary-adrenal axis. Increased BDNF levels can reduce the expression of inflammatory cytokines, oxidative stress and the risk of malnutrition [61]. The correct balance of microbiota aids in proper absorption of nutrients. It has been shown that intestinal bacteria increase intestinal absorption of, e.g., PUFAs from the omega-3 family and polyphenols [23].

Probiotics supplementation can be used in the treatment of depressive disorders. An 8-week supplementation with Lactobacillus acidophilus, Lactobacillus casei and Bifidobacterium bifidum improved symptoms of depression as compared to placebo treatment. Patients also showed a significant reduction in inflammatory markers, insulin levels, and serum C-reactive protein. Moreover, authors observed increased glutathione concentration and improved insulin sensitivity [42].

\section{BRANCHED-CHAIN AMINO ACIDS}

Evidence suggests that diabetes is a risk factor for AD, because altered insulin signaling impairs metabolism of lipids and branched-chain amino acids (BCAAs) in peripheral organs such as the liver and adipose tissue [33]. Therefore, patients with diabetes and $\mathrm{AD}$ have higher plasma BCAA concentration $[47,59]$. Branched chain amino acids include valine, leucine, and isoleucine.
Animal studies have shown that although leucine increases tau phosphorylation, it does not affect amyloid- $\beta$ accumulation in nervous tissue [33]. Mice fed with BCAA-enriched diet displayed cognitive impairment and higher mortality, although their motor functions were not impaired. In contrast, mice on the low-BCAA diet showed higher cortical threonine and tryptophan levels (and hence serotonin) and performed better on the novel object recognition task [59]. Researchers suggest that excessive intake of BCAA inhibits transport of other amino acids to the brain, which can directly influence synthesis of different neurotransmitters [33].

It has been shown that impaired BCAA metabolism may contribute to the development of dementia and AD may increase the risk of diabetes. Therefore, plasma BCAA concentration is a potential biomarker for metabolic diseases in patients with AD [47].

Increased dietary intake of BCAA has been found to give the same results as supplementation. Meat, fish, eggs, brazil nuts and peanuts are particularly rich in BCAA. Smaller amounts of BCAA can be found in other nuts, legume seeds and soybean products like tofu or tempeh [46].

\section{DIETS IN ALZHEIMER'S DISEASE}

Mediterranean diet can be recommended for patients with AD. This dietary pattern characterized by the abundant consumption of whole grains, fruits, vegetables, pulses, fish, olive oil; moderate intake of dairy products and alcohol (mainly dry red wine); and low consumption of foods rich in saturated fatty acids, such as meat. This diet is rich in antioxidants, $B$ vitamins and unsaturated fatty acids [43, 50]. It has been shown that Mediterranean diet not only reduces inflammation and oxidative stress, but is also associated with reduced loss of brain volume and slower progression of $\mathrm{AD}[4,48]$. In addition, it reduces the risk of cardiovascular disease, cancer, type 2 diabetes, and metabolic syndrome. These diseases have a significant impact on the development of dementia, therefore their prevention is also an element of AD prevention [53,60].

The Dietary Approaches to Stop Hypertension (DASH) diet shares similarities with the Mediterranean diet, as it also involves high intakes of fruits, vegetables, low-fat dairy products and whole grains, vitamins and antioxidants. In addition, DASH diet is rich in minerals such as potassium, magnesium and calcium, and emphasizes the limited intake of refined grain products, sodium and SFAs [53]. However, DASH diet is not effective in alleviating symptoms of $\mathrm{AD}$; it only lowers the risk of disease occurrence. This diet prevents cardiovascular diseases such as arterial hypertension and has a beneficial effect on 
the lipid profile $[44,48]$. The positive effects of the implementation of the DASH diet are a consequence of its use for a long time, even before the first symptoms of dementia, and can only be used in the prevention of cognitive disorders [11].

A combination of the Mediterranean and DASH diets is called the MIND diet (MIND stands for Mediterranean-DASH Intervention for Neurodegenerative Delay). This diet is designed to improve cognitive performance and lower the risk of developing neurodegenerative diseases such as AD. In addition to DASH and Mediterranean diets, MIND diet emphasizes the consumption of food products that have a positive effect on brain function such as green leafy vegetables (spinach, kale, lettuce) and berries (strawberries, blueberries, blueberries and raspberries). These products should be eaten 6 times a week. Other food products recommended on the MIND diet include vegetables, nuts, pulses, whole grains, fish, poultry, olive oil, and red wine. On the other hand, the MIND diet encourages limiting the consumption of red meat, butter, margarine, cheese, sweets and fried foods. The above modifications to the diet turned out to be strongly correlated with the lower risk of cognitive disorders. The MIND diet is much more effective in preventing dementia than the Mediterranean diet and the DASH diet alone [26, 39].

\section{SUMMARY}

The diet of patients with AD should be balanced and provide the right amount of energy. Elderly people should know the principles of rational nutrition and remain independent for as long as possible, because this will help slow down the progression of the disease. For this reason, third parties should provide help only if necessary. The clinical value of antioxidants for the prevention of $\mathrm{AD}$ is ambiguous. Vitamins $\mathrm{C}$ and $\mathrm{A}$ do not inhibit the progression of cognitive disorders. Research on the protective effect of vitamin $\mathrm{E}$ is contradictory. However, research has revealed that curcumin not only prevents aggregation of new amyloid- $\beta$ deposits, but also reduces the size of remaining ones. Vitamins B6, B12 and folic acid maintain a healthy nervous system and may be helpful in the treatment of AD. Supplementation should be considered with a physician if such amounts of vitamins cannot be supplied with the diet. Excessive intake of saturated fatty acids can aggravate cognitive disorders. On the other hand, consuming unsaturated fatty acids prevents cognitive decline. Hyperuricemia may prevent the development of dementia and alleviate the disease course of AD. Caffeine may protect against cognitive disorders and dementia due to its neuroprotective and neuromodulatory properties. Probiotics, particularly Lactobacillus spp., can improve synaptic plasticity, stimulate hippocampal neurogenesis, regulate hypothalamicpituitary-adrenal (HPA) axis and reduce the level of oxidative stress. High levels of BCAA may contribute to cognitive decline and higher mortality. However, a diet low in these amino acids may indirectly raise brain serotonin levels.

The Mediterranean diet not only reduces inflammation and oxidative stress, but is also associated with reduced loss of brain volume and slower AD progression. DASH diet has positive results if followed for a longer period of time, even before the first symptoms of dementia begin to appear, and therefore it can only be used as the prevention of cognitive decline. However, the MIND diet turned out to be much more effective in preventing dementia than the Mediterranean and DASH diets alone.

\section{Conflict of interest}

The authors declare no conflict of interest.

\section{REFERENCES}

1. Al-khateeb E., Althaher A., Al-khateeb M., Al-Musawi H., Azzouqah O., Al-Shweiki S., Shafagoj Y.: Relation between uric acid and Alzheimer's disease in elderly Jordanians. J Alzheimers Dis. 2015, 44, 859-65. doi: 10.3233/JAD-142037.

2. Alzoubi K.H., Mhaidat N.M., Obaid E.A., Khabour O.F.: Caffeine Prevents Memory Impairment Induced by Hyperhomocysteinemia. J Mol Neurosci. 2018, 66, 222-228. doi:10.1007/s12031-018-1158-3.

3. Arendash G., Cao C.: Caffeine and Coffee as Therapeutics Against Alzheimer's Disease. J Alzheimers Dis. 2010, 20, 117-26. doi: 10.3233/JAD-2010-091249.

4. Aridi Y., Walker J., Wright O.: The Association between the Mediterranean Dietary Pattern and Cognitive Health: A Systematic Review. Nutrients. 2017, 9, 674. doi: 10.3390/nu9070674.

5. Barcikowska M.: Otępienie, 2226-2230. In: Gajewski P., Szczeklik A.: Interna. Medycyna Praktyczna, Kraków, 2019.

6. Binyamin O., Nitzan K., Frid K., Ungar Y., Rosenmann H., Gabizon R.: Brain targeting of 9c,11t-Conjugated Linoleic Acid, a natural calpain inhibitor, preserves memory and reduces $\mathrm{A} \beta$ and P25 accumulation in 5XFAD mice. Sci Rep. 2019, 9, 18437. doi: 10.1038/ s41598-019-54971-9.

7. Birkner E., Zalejska-Fiolka J., Antoszewski Z.: Aktywność enzymów antyoksydacyjnych i rola witamin o charakterze antyoksydacyjnym w chorobie Alzheimera [Antioxidant enzymes activity and role of antioxidant vitamins in Alzheimer disease] Post Hig. 2004, 58, 264-269 (in Polish).

8. Blusztajn J., Slack B., Mellott T.: Neuroprotective Actions of Dietary Choline. Nutrients. 2017, 9, 815. doi: 10.3390/nu9080815. 
9. Boada M., Palacio-Lacambra M.E., Palasi-Franco A., Rodríguez-Gómez O., Ruiz-Laza A.: Prevention of Alzheimer's disease: a global challenge for next generation neuroscientists. J Alzheimers Dis. 2014, 42, 515-23.

10. Campdelacreu J.: Parkinson disease and Alzheimer disease: environmental risk factors. Neurologia. 2014, 29, 541-9. doi: 10.1016/j.nrl.2012.04.001.

11. Cremonini A.L., Caffa I., Cea M., Nencioni A., Odetti P., Monacelli F.: Nutrients in the Prevention of Alzheimer's Disease. Oxid Med Cell Longev. Oxid Med Cell Longev. 2019; 2019: 9874159. doi: 10.1155/2019/9874159.

12.Crous-Bou M., Minguillón C., Gramunt N., Molinuevo J.L.: Alzheimer's disease prevention: from risk factors to early intervention. Alzheimers Res Ther. 2017, 9, 71. doi: 10.1186/s13195-017-0297-z.

13. De Jesus Moreno Moreno M.: Cognitive improvement in mild to moderate Alzheimer's dementia after treatment with the acetylcholine precursor choline alfoscerate: a multicenter, double-blind, randomized, placebo-controlled trial. Clin Ther. 2003, 25, 178-93. doi: 10.1016/s0149-2918(03)90023-3.

14. EFSA Panel on Dietetic Products, Nutrition and Allergies (NDA): Scientific Opinion related to the Tolerable Upper Intake Level of eicosapentaenoic acid (EPA), docosahexaenoic acid (DHA) and docosapentaenoic acid (DPA). EFSA Journal. 2012, 10, 2815. doi:10.2903/j.efsa.2012.2815.

15.Dochniak M., Ekiert K.: Żywienie w prewencji i leczeniu choroby Alzheimera i choroby Parkinsona [Nutrition in Prevention and Treatment of Alzheimer's and Parkinson's Diseases] Piel Zdr Publ. 2015, 5, 2, 199-208 (in Polish).

16. Galloway S., Takechi R., Nesbit M., PallebageGamarallage M.M., Lam V., Mamo J.C.L.: The differential effects of fatty acids on enterocytic abundance of amyloid-beta. Lipids Health Dis 2019;18, 209. doi:10.1186/s12944-019-1162-9.

17. Gama M.A.S., Raposo N.R.B., Mury F.B., Lopes F.C.F., Dias-Neto E., Talib L.L., Gattaz W.F.: Conjugated linoleic acid-enriched butter improved memory and up-regulated phospholipase A2 encoding-genes in rat brain tissue. J Neural Transm. 2015, 122, 1371-80. doi: 10.1007/s00702-015-1401-9.

18. Garcia-Alloza M., Borrelli L.A., Rozkalne A., Hyman B.T., Bacskai B.J.: Curcumin labels amyloid pathology in vivo, disrupts existing plaques, and partially restores distorted neurites in an Alzheimer mouse model. J Neurochem. 2007, 102, 1095-104. doi: 10.1111/j.14714159.2007.04613.x.

19. Gomes B.A.Q., Silva J.P.B., Romeiro C.F.R., dos Santos S.M., Rodrigues C.A., Gonçalves P.R., SakaiJ.T., Mendes P.F.S., Varela E.L.P., Monteiro M.C.: Neuroprotective Mechanisms of Resveratrol in Alzheimer's Disease: Role of SIRT1. Oxid Med Cell Longev. Oxid Med Cell Longev 2018;8152373. doi:10.1155/2018/8152373.

20.Gómez-Cortés $P$, de la Fuente MÁ, Juárez M.: Trans fatty acids and conjugated linoleic acid in food: origin and biological properties. Nutricion Hospitalaria 2019;36(2):479-486. doi: 10.20960/nh.2466 (in Spanish).
21. Gonzales G.B., Smagghe G., Grootaert C., Zotti M., Raes K., Van Camp J.: Flavonoid interactions during digestion, absorption, distribution and metabolism: a sequential structure-activity/property relationshipbased approach in the study of bioavailability and bioactivity. Drug Metab Rev. 2015, 47, 175-90. doi: 10.3109/03602532.2014.1003649.

22.Healy-Stoffel M., Levant B.: N-3 (Omega-3) Fatty Acids: Effects on Brain Dopamine Systems and Potential Role in the Etiology and Treatment of Neuropsychiatric Disorders.CNSNeurolDisordDrug Targets. 2018;17:216232. doi: $10.2174 / 1871527317666180412153612$.

23.Hu X., Wang T., Jin F.: Alzheimer's disease and gut microbiota. Sci China Life Sci. 2016, 59, 1006-1023. doi:10.1007/s11427-016-5083-9.

24.Jarosz M., Rychlik E., Stoś K., Charzewska J.: Normy Żywienia dla populacji Polski i ich zastosowanie. (Nutrition standards for the Polish population and their application). Państwowy Zakład Higieny, 2020 (in Polish).

25.Jiang C., Li G., Huang P., Liu Z., Zhao B.: The Gut Microbiota and Alzheimer's Disease. J Alzheimers Dis. 2017, 58, 1-15. doi: 10.3233/JAD-161141.

26.KaluźniakA., Krzymińska-SiemaszkoR., WieczorowskaTobis K.: Wpływ diety na zachowanie sprawności funkcji poznawczych przez osoby starsze - możliwości zdrowotne wynikające ze stosowania diety MIND [The impact of diet on maintaining cognitive function by the elderly - health potential resulting from the use of the MIND diet]. Geriatria. 2018, 12, 110-116 (in Polish).

27. Karpińska A., Gromadzka G.: Stres oksydacyjny i naturalne mechanizmy antyoksydacyjne - znaczenie w procesie neurodegeneracji. Od mechanizmów molekularnych do strategii terapeutycznych [Oxidative stress and natural antioxidant mechanisms: the role in neurodegeneration. From molecular mechanisms to therapeutic strategies] Post Hig. 2013, 67, 43-53 (in Polish).

28.Kesse-Guyot E., Fezeu L., Andreeva V., Touvier M., Scalbert A., Hercberg S., Galan P.: Total and specific polyphenol intakes in midlife are associated with cognitive function measured 13 years later. J Nutr. 2012, 142, 76-83. doi: 10.3945/jn.111.144428.

29. Komaki H., Faraji N., Komaki A., Shahidi S., Etaee F., Raoufi S., Mirzaei F.: Investigation of protective effects of coenzyme Q10 on impaired synaptic plasticity in a male rat model of Alzheimer's disease. Brain Res Bull. 2019, 147, 14-21. doi: 10.1016/j.brainresbull.2019.01.025.

30. Kopeć A., Piatkowska E., Leszczyńska T., BieżanowskaKopeć R.: Prozdrowotne właściwości resweratrolu [Health Stimulating Properties of Resveratrol] Żywn Nauka Technol Jakość. 2011, 5, 5-15 (in Polish).

31. Külzow N., Witte A.V., Kerti L., Grittner U., Schuchardt J.P., Hahn A., Flöel A.: Impact of Omega-3 Fatty Acid Supplementation on Memory Functions in Healthy Older Adults. J Alzheimers Dis . 2016, 51, 713-25. doi: 10.3233/JAD-150886.

32.Lee M., Choi B., Suh S.: Unexpected Effects of Acetylcholine Precursors on Pilocarpine SeizureInduced Neuronal Death. Curr Neuropharmacol. 2018, 16, 51-58. doi: 10.2174/1570159X15666170518150053. 
33. Li H., Ye D., Xie W., Hua F., Yang Y., Wu J., Gu A., Ren Y., Mao K.: Defect of branched-chain amino acid metabolism promotes the development of Alzheimer's disease by targeting the mTOR signaling. Biosci Rep. 2018, 38. doi: 10.1042/bsr20180127.

34.Livingston G., Sommerlad A., Orgeta V., Costafreda S.G., Huntley J., Ames D., Ballard C., Banerjee S., Burns A., Cohen-Mansfield J., Cooper C., Fox N., Gitlin L.N., Howard R, Kales H.C., Larson E.B., Ritchie K., Rockwood K., Sampson E.L., Samus Q., Schneider L.S., Selbcek G., Teri L., Mukadam N.: Dementia prevention, intervention, and care. Lancet. 2017, 16, 2673-2734. doi: 10.1016/S0140-6736(17)31363-6.

35. Lopez O., Kuller L.: Epidemiology of aging and associated cognitive disorders: Prevalence and incidence of Alzheimer's disease and other dementias. Handb Clin Neurol. 2019, 167, 139-148. doi: 10.1016/ B978-0-12-804766-8.00009-1.

36. Magierski R., Antczak-Domagała K., Sobów T.: Dieta jako czynnik protekcyjny otępienia [Diet as a protective factor in dementia] Aktualn Neurol. 2014, 14, 167-174. (in Polish). doi: 10.15557/AN.2014.0019.

37. Materac E., Marczyński Z., Bodek K.: Rola kwasów tłuszczowych omega-3 i omega-6 w organizmie człowieka [The role of long-chain fatty acids omega-3 and omega- 6 in human body] Bromat Chem Toksykol. 2013, 2, 225-233 (in Polish).

38. Mecocci P., Boccardi V., Cecchetti R., Bastiani P., Scamosci M., Ruggiero C., Baroni M.: A Long Journey into Aging, Brain Aging, and Alzheimer's Disease Following the Oxidative Stress Tracks. J Alzheimers Dis. 2018, 62, 1319-1335. doi: 10.3233/JAD-170732.

39. Morris M.C., Tangney C.C., Wang Y., Sacks F.M., Barnes L.L., Bennett D.A., Aggarwal N.T.: MIND diet slows cognitive decline with aging. Alzheimers Dement. 2015, 11, 1015-22. doi: 10.1016/j.jalz.2015.04.011.

40.Morris M.S., Selhub J., Jacques P.F.: Vitamin B-12 and folate status in relation to decline in scores on the mini-mental state examination in the framingham heart study. J Am Geriatr Soc. 2012, 60, 1457-64. doi: 10.1111/j.1532-5415.2012.04076.x.

41. Oboudiyat C., Glazer H., Seifan A., Greer C., Isaacson R.S.: Alzheimer's disease. Semin Neurol. 2013, 33, 31329. doi:10.1055/s-0033-1359319.

42.Park C., Brietzke E., Rosenblat J.D., Musial N., Zuckerman H., Ragguett R-M., Pan Z., Rong C., Fus D, McIntyre R.S.: Probiotics for the treatment of depressive symptoms: An anti-inflammatory mechanism? Brain Behav Immun. 2018, 73, 115-124. doi: 10.1016/j. bbi.2018.07.006.

43. Petersson S., Philippou E.: Mediterranean Diet, Cognitive Function, and Dementia: A Systematic Review of the Evidence. Adv Nutr. 2016, 7, 889-904. doi: 10.3945/an.116.012138.

44.Pistollato F., Iglesias R.C., Ruiz R., Aparicio S., Crespo J., Lopez L.D., Manna P.P., Giampieri F., Battino M.: Nutritional patterns associated with the maintenance of neurocognitive functions and the risk of dementia and Alzheimer's disease: A focus on human studies. Pharmacol Res. 2018, 131, 32-43. doi: 10.1016/j. phrs.2018.03.012.
45.Reddy P.H., Manczak M., Yin X., Grady M.C., Mitchell A., Tonk S., Kuruva C.S., Bhatti J.S., Kandimalla R., Vijayan M., Kumar S., Wang r., Pradeepkiran J.A., Ogunmokun G., Thamarai K., Quesada K., Boles A., Reddy A.P.: Protective Effects of Indian Spice Curcumin Against Amyloid- $\beta$ in Alzheimer's Disease. J Alzheimers Dis. 2018, 61, 843-866. doi: 10.3233/jad170512.

46.Rousseau M., Guénard F., Garneau V., Allam-Ndoul B., Lemieux S., Pérusse L., Vohl M.C.: Associations Between Dietary Protein Sources, Plasma BCAA and Short-Chain Acylcarnitine Levels in Adults. Nutrients. 2019, 11, 173. doi: 10.3390/nu11010173.

47. Ruiz H.H., Chi T., Shin A.C., Lindtner C., Hsieh W., Ehrlich M., Gandy S., Buettner C.: Increased susceptibility to metabolic dysregulation in a mouse model of Alzheimer's disease is associated with impaired hypothalamic insulin signaling and elevated BCAA levels. Alzheimers Dement. 2016, 12, 851-61. doi: 10.1016/j.jalz.2016.01.008.

48.Samadi M., Moradi S., Moradinazar M., Mostafai R., Pasdar $Y$.: Dietary pattern in relation to the risk of Alzheimer's disease: a systematic review. Neurol Sci. 2019, 40, 2031-2043. doi: 10.2174/156720511796391836.

49.Sawikr Y., Yarla N.S., Peluso I., Kamal M.A., Aliev G., Bishayee A.: Neuroinflammation in Alzheimer's Disease: The Preventive and Therapeutic Potential of Polyphenolic Nutraceuticals. Adv Protein Chem Struct Biol. 2017, 108, 33-57. doi: 10.1016/bs.apcsb.2017.02.001.

50. Scarmeas N., Anastasiou C., Yannakoulia M.: Nutrition and prevention of cognitive impairment. Lancet Neurol. 2018, 17, 1006-1015. doi: 10.1016/S1474-4422(18)30338-7.

51. Siemieniuk E., Skrzydlewska E.: Koenzym Q10 biosynteza i znaczenie biologiczne w organizmach zwierząt i człowieka [Coenzyme Q10: its biosynthesis and biological signifi cance in animal organisms and in humans] Post Hig. 2005, 59, 150-159 (in Polish).

52. Silva M.V.F., Loures C.M.G., Alves L.C.V., de Souza L.C., Borges K.B.G., das Graças Carvalho M.: Alzheimer's disease: risk factors and potentially protective measures. J Biomed Sci. 2019, 26, 33. doi: 10.1186/s12929-0190524-y.

53.Solfrizzi V., Custodero C., Lozupone M., Imbimbo B.P., Valiani V., Agosti P., Schilardi A., D'Introno A., La Montagna M., Calvani M., Guerra V., Sardone R.,Abbrescia D.I., Bellomo A., Greco A., Daniele A., Seripa D., Logroscino G., Sabbá C, Panza F.: Relationships of Dietary Patterns, Foods, and Microand Macronutrients with Alzheimer's Disease and Late-Life Cognitive Disorders: A Systematic Review. J Alzheimers Dis. 2017, 59, 815-849. doi: 10.3233/JAD17024

54. Spitsin S., Koprowski H.: Role of uric acid in Alzheimer's disease. J Alzheimers Dis. 2010;19:1337-8. doi: 10.3233/ JAD-2010-1336.

55. Szablewski L.: Human Gut Microbiota in Health and Alzheimer's Disease. J Alzheimers Dis. 2018;62:549560. doi: 10.3233/JAD-170908.

56.Szczygiet B., Gawet M., Ukleja A., Boniecka I.: Rola wybranych składników odżywczych we wspomaganiu leczenia farmakologicznego choroby Alzheimera. 
[The role of selected nutrients in supporting the pharmacological treatment of Alzheimer's disease] Med Wieku Podeszłego. 2014;4:7-15 (in Polish).

57. Tana C., Ticinesi A., Prati B., Nouvenne A., Meschi T.: Uric Acid and Cognitive Function in Older Individuals. Nutrients. 2018, 10, 975. doi: 10.3390/nu10080975.

58. Tang M., Taghibiglou C.: The Mechanisms of Action of Curcumin in Alzheimer's Disease. J Alzheimers Dis. 2017;58:1003-1016. doi: 10.3233/JAD-170188.

59. Tournissac M., Vandal M., Tremblay C., Bourassa P., Vancassel S., Emond V., Gangloff A., Calon F.: Dietary intake of branched-chain amino acids in a mouse model of Alzheimer's disease: Effects on survival, behavior, and neuropathology. Alzheimers Dement. 2018;4, 677687. doi: 10.1016/j.trci.2018.10.005.

60.van de Rest O., Berendsen A.A.M., Haveman-Nies A., de Groot L.CPGM.: Dietary patterns, cognitive decline, and dementia: a systematic review. Adv Nutr. 2015;6: 154-68. doi: 10.3945/an.114.007617.

61. van Giau V., Ying Wu S., Jamerlan A., An S.S.A., Yun Kim S., Hulme J.: Gut Microbiota and Their Neuroinflammatory Implications in Alzheimer's Disease. Nutrients. 2018;10:1765. doi: 10.3390/ nu10111765.

62.Vauzour D.: Effect of flavonoids on learning, memory and neurocognitive performance: relevance and potential implications for Alzheimer's disease pathophysiology. J Sci Food Agric. 2014;94:1042-1056. doi: $10.1002 /$ jsfa.6473.

63. Walczewska A., Stępień T., Bewicz-Binkowska D., Zgórzyńska E.: Rola kwasu dokozaheksaenowego w czynności komórek nerwowych [The role of docosahexaenoic acid in neuronal function]. Post Hig. 2011;65:314-327 (in Polish).
64.Weller J., Budson A.: Current understanding of Alzheimer's disease diagnosis and treatment. 2018, 7: F1000 Faculty Rev-1161. doi: 10.12688/f1000research.

65. Wichlińska-Lipka M., Nyka W.M.: Rola homocysteiny w patogenezie chorób układu nerwowego. Forum Med Rodz. 2008;2:223-228.

66. Wiedeman A.M., Barr S.I., Green T.J., Xu Z., Innis S.M., Kitts D.D.: Dietary Choline Intake: Current State of Knowledge Across the Life Cycle. Nutrients. 2018;10:1513. doi: 10.3390/nu10101513.

67. Wierzejska R.: Can coffee consumption lower the risk of Alzheimer's disease and Parkinson's disease? A literature review. Arch Med Sci. 2017, 13, 507-514. doi: 10.5114/aoms.2016.63599.

68.Wu G., Fang Y-Z., Yang S., Lupton J.R., Turner N.D.: Glutathione metabolism and its implications for health. J Nutr. 2004, 134, 489-92. doi: 10.1093/jn/134.3.489.

69. Yang F., Lim G.P., Begum A.N., Ubeda O.J., Simmons M.R., Ambegaokar S.S., Chen P.P., Kayed R., Glabe C.G., Frautschy S.A., Cole G.M.: Curcumin inhibits formation of amyloid beta oligomers and fibrils, binds plaques, and reduces amyloid in vivo. $\mathrm{J}$ Biol Chem. 2005;280:5892-901. doi: 10.1074/jbc.M404751200.

70. Ye B.S., Lee W.W., Ham J.H., Lee J.J., Lee P.H., Sohn Y.H.: Does serum uric acid act as a modulator of cerebrospinal fluid Alzheimer's disease biomarker related cognitive decline? Eur J Neurol. 2016;23:948-57. doi: 10.1111/ene.12969.

Received: 01.12.2020

Accepted: 03.02.2021 